\title{
The efficacy of some medicinal plants used locally within Transmara west, Narok County, Kenya against selected Enterobacteria and Candida
}

\author{
Hesbon Omwoyo Nyang'au ${ }^{1}$, John Maingi ${ }^{2}$, Anthony Kebira ${ }^{3}$ \\ ${ }^{11}$ Department of Biological Sciences, Rongo University, Rongo, Kenya) \\ ${ }^{21}$ Department of Microbiology, Kenyatta University, Nairobi, Kenya) \\ ${ }^{3(}$ Department of Microbiology, Kenyatta University, Nairobi, Kenya)
}

\begin{abstract}
The bacterial family Enterobacteriaceae and fungal genus Candida have continued to be a great challenge worldwide including resistance to antibiotics and relapse of infections mediated by them. Among these organisms, Salmonella typhi, Shigella species, Klebsiella pneumoniae and Escherichia coli strains have emerged as the most frequent cause of diarrheal illnesses which account for an annual mortality rate of 4.6 million people worldwide and many other infections. Candida albicans has been reported as a causative agent of all types of candidiasis. In the present study, the efficacy of plants commonly used plants in Transmara west, Kenya against these microbes was investigated. An ethnobotanical survey using semi-structured questionnaire was done. Plant extracts were obtained through methanolic extraction. Antimicrobial susceptibility assay was done using Kirby Bauer disk diffusion technique. Minimum inhibitory Concentration (MIC), Minimum Bactericidal Concentration (MBC) for the bacterial test stains and Minimum Fungicidal Concentration (MFC) for C. albicans were determined using microtitre broth dilution method. Phytochemical tests were done using standard procedures. The study validates the ethno-medicinal use of Pterolobium stellatum, Rhamnus prinoides, Phyllanthus urinaria, Carissa edulis, Clutia abyssinica, Clerodendrum rotundifolium, Clerodendron myricoides and Dovyalis abyssinica and recommends consideration for the use of the studied plants as possible sources of antimicrobial agents in the development of drugs for treatment of Enterobacteria and Candida related infections.
\end{abstract}

Keywords: Efficacy, Enterobacteria, Medicinal, Phytochemicals, Transmara west

\section{Introduction}

Salmonella typhi, Shigella dysenteriae, Klebsiella pneumonia and Escherichia coli represent members of the Enterobacteriaceae family largely implicated as causes of urinary tract infections (UTIs), many bloodstream infections, nosocomial pneumonias, various intra-abdominal infections and diarrhoea $[1,2,3]$. It is estimated that 4 billion diarrheal infections and 4.6 million people, including 2.5 million children deaths occur from diarrhea every year particularly in developing countries [4]. According to Sobel (2009) [5], C. albicans is the cause of up to about $85-95 \%$ of all vulvovaginal candidiasis (VVC). It has been observed that VVC is one of the most common vaginal infections with about 50 to $75 \%$ women suffering symptomatic disease and $5 \%$ developing recurring VVC [6].

High levels of resistance to commonly used antibiotics have often been recorded among this group of bacteria worldwide [7, 8]. In the last two decades, outbreaks of infections caused by extended-spectrum blactamase (ESBL)-producing Enterobacteriaceae have largely been reported [9, 10]. Among other ESBL producers, Escherichia coli and Klebsiella pneumoniae have been implicated as the main gram- negative bacteria that are associated with production of these enzymes which are responsible for multi-drug resistance $[11,12,13]$.

Infection with carbapenemase-producing Enterobacteriaceae is another emerging important challenge in health-care settings [14]. A progressive increase in Carbapenem-Resistant Klebsiella pneumoniae (CRKP) strain has been observed worldwide over the last decade posing a great challenge in healthcare settings since carbapenem is often used as a drug of last resort in the treatment of diseases caused by resistant bacterial strains $[15,16]$. Multi-drug resistant (MDR) Salmonella and Shigella disenteriae type 1 strains have also been identified and recorded to have escalated into a worldwide problem $(17,18)$.

Additionally, many antifungal drugs including imidazoles, triazoles and thiazoles have limitations such as a narrow spectrum of action, undesirable side effects, toxicity and emergence of drug resistance [5, 19]. This has posed a challenge in the management of Candida infections. The problem of recurrence of infections caused by bacterial and fungal organisms and the emergence of antimicrobial resistance has therefore led to the increased interest in herbal products [20]. Plants have been proven to be important both as agents of pharmacological research and drug development by acting as sources of lead compounds for synthesis of drugs 
The efficacy of some medicinal plants used locally within Transmara west, Narok County, Kenya ..

or when used directly as therapeutic agents and therefore reducing total dependence on antibiotics [21,22]. The objective of our study was to identify some of the plants commonly used against Salmonella typhi, Shigella species, Klebsiella pneumoniae, Escherichia coli and Candida albicans by traditional herbal practitioners of the Maasai community in Transmara west sub-county, Kenya, investigate their antimicrobial activity in vitro and subject them to phytochemical assay to test for presence of saponins, tannins, alkaloids and flavonoids. The study site was purposely selected since it is known to be rich in indigenous vegetation and also the use of medicinal herbs for treatment of various ailments which is relatively substantial [23].

\subsection{Ethnobotanical survey}

\section{Materials And Methods}

The study area (Tranamara west sub-county) was divided into six blocks which comprised the six divisions in Transmara west namely Kilgoris, Keiyian, Lolgorian, Angata, Pirrar and Kirindon. Key informants comprising of Traditional Health Practitioners (THP) knowledgeable on medicinal plants used for treating various diseases were identified with the help of local leaders including chiefs and village elders. Selection of informants to participate in the study was done using purposive sampling technique [24]. The selection depended on the willingness to share information and acquaintance with medicinal plants used for treating diseases such as pneumonia, candidiasis and diarrhea. With the help of the local leaders, twelve informants were selected by identifying two knowledgeable informants from each of the six divisions.

Information on medicinal plants used was collected through interviews using a semi-structured questionnaire as well as detailed personal discussion with the herbalists [25]. The plants used by the THP in the management of diseases whose symptoms were associated with Salmonella typhi, Klebsiella pneumoniae, E. coli, Shigella dysenteriae and C. albicans were first identified using their vernacular names. Then the plants commonly identified were selected using the 'species of choice value' model [26].

To further select medicinal plants for screening, a participatory pair-wise ranking exercise [27] was conducted with confinement to only those plants whose use was restricted to the treatment of typhoid, dysentery, pneumonia, diarrhoea and candidiasis. This involved a prioritization exercise involving participation of the herbalists. During the exercise, a list of plants cited in the questionnaire for treatment of fungal and enterobacteria related infections was generated. Selection of plants was by agreement of herbalists, whereby frequency of use of a given species and comparison between different species used for treatment of the same disease were considered. With the guidance of informants, the habitats of the selected plants were located then the parts of the plants used in the treatment of the respective diseases, as specified by the informants were collected. Voucher specimens were also collected and preserved in a plant press. Identification of the plants was done at the Department of Plant and Microbial Sciences in Kenyatta University.

\subsection{Collection, identification and drying of plant samples}

After an ethnobotanical survey on plants used by traditional health practitioners in Transmara West against the selected pathogens, plant parts, which comprised roots of the sampled plants were collected as prescribed by the herbalists and transported for screening at the University. The samples were chopped into pieces and air dried in the laboratory for three weeks and then ground into powder using a milling machine and stored in sterilized bottles.

\subsection{Extraction of chemical substances}

The ground powder was first soaked in methanol for 3 days before decanting and filtering through a Buchner funnel using Whatman filter paper No. 42. The filtrate was concentrated using a rotary evaporator (Type N-100, SN 60714679, Eyela- Tokyo) with the water bath set at $40{ }^{\circ} \mathrm{C}$. This was followed by drying of the extracts in a dessicator over anhydrous Calcium Sulphate [28]. The extracts were then stored at $4{ }^{\circ} \mathrm{C}$ for further use [29].

\subsection{Sourcing of test microorganisms}

Clinical isolates of Salmonella typhi, Klebsiella pneumoniae, E. coli, Shigella dysenteriae and C. albicans strains were obtained from Kenyatta National Hospital, Kenya, during the period of the assay and transported to Kenyatta University for antimicrobial susceptibility testing.

\subsection{Antimicrobial susceptibility assay}

Kirby Bauer disk diffusion technique was used [30]. A plant extract concentration of $300 \mathrm{mg} / \mathrm{ml}$ was prepared using methanol as the solvent. For the test isolates, an inoculum size of 0.5 McFarland standard was used. The test bacterial cultures were applied by spreading $0.1 \mathrm{ml}$ of the bacterial inoculums on dry $150 \mathrm{~mm}$ diameter Mueller-Hinton agar plate [31]. Twelve disks $(6 \mathrm{~mm}$ diameter) were then soaked in $0.1 \mathrm{ml}$ of the dissolved plant extracts. Commercial antibiotic Ciprofloxacin was used as the positive control for the bacterial 
The efficacy of some medicinal plants used locally within Transmara west, Narok County, Kenya ..

isolates while methanol was used as a negative control. The disks were then air dried and placed on the inoculums' agar surface separately. Incubation was done for 24 hours at $35 \pm 2{ }^{\circ} \mathrm{C}$ before analysis.

For $C$. albicans, the disks were soaked in $0.1 \mathrm{ml}$ of the plant extracts, commercial antifungal fluconazole as positive control and methanol as negative control. Dry impregnated disks were spread on prepared dry Potato Dextrose Agar (PDA) plates containing spread $0.1 \mathrm{ml}$ of $C$. albicans inoculum. The plates were then incubated for 24 hours at $35 \pm 2{ }^{\circ} \mathrm{C}$. Three replicates of the extract and control impregnated disks were made for every test microbe. Microbial growth inhibition was determined by measuring the average zones of inhibition to the nearest millimeter using a transparent plastic ruler [32]. Based on the size of average zones of inhibition, the susceptibility levels by the test pathogens to the crude plant extracts were categorized as resistant (average zone of inhibition of $\leq 7.00 \mathrm{~mm}$ ), intermediately resistant (average zone of inhibition of between $>7.00 \mathrm{~mm}$ and $<$ $9.00 \mathrm{~mm}$ ) and susceptible (average zone of inhibition $\geq 9.00 \mathrm{~mm}$ ) [28].

\subsection{Determination of Minimum inhibitory concentrations (MICs) and Minimum Bactericidal Concentration/Minimum Fungicidal concentrations}

The active extracts which recorded mean zones of inhibition of $\geq 9 \mathrm{~mm}$ from the antimicrobial susceptibility test by Kirby Bauer disk diffusion method were tested for MIC and MBC/MFC [33]. The MIC was determined by use of Micro-titre broth dilution method [34] using a 96- well micro-titre plate. A solution of plant extract (concentration of $300 \mathrm{mg} / \mathrm{ml}$ ) was prepared using 2\% DMSO as solvent [35].

All the wells were first filled with fifty microlitres $(50 \mu \mathrm{l})$ of broth. Fifty microlitres of the prepared plant extract solution was then dispensed into the first well then two- fold serial dilutions of $50 \mu 1$ of broth mixed with the extract were carried out until the eleventh well was reached, at which time the last $50 \mu 1$ was discarded [34]. Fifty micro litres $(50 \mu \mathrm{l})$ of broth containing the standardised test microorganism isolate was then dispensed into each well. One well with $50 \mu \mathrm{l}$ of the antibiotic ciprofloxacin/fluconazole was used as positive control while another well without extract or antibiotic was used as the negative control. Incubation was done at $37{ }^{\circ} \mathrm{C}$ for 24 hours and microbial growth confirmed by visible turbidity. Minimum Inhibitory Concentration was represented by the lowest concentration of the extract that prevented visible growth [36].

Broth was then taken from each well without visible microbial growth and then sub-cultured onto fresh drug-free solid media (Nutrient broth for bacterial isolates and PDA broth for C. albicans) and incubated for further 24 hrs. The MBCs and MFCs were defined as the lowest concentrations of the extracts that completely killed the inoculated microbial population [34].

\subsection{Test for saponins, tannins, flavonoids and alkaloids}

The plant extracts were subjected to phytochemical screening in order to test for the presence of saponins, tannins, flavonoids and alkaloids [37]. Screening for presence of the selected phytochemicals was carried out using standard procedures $[38,39,40]$.

\subsection{Data analysis}

Data obtained from the zones of inhibition was analyzed using SPSS version 16 computer program. The average zones of inhibition values produced by the plant extracts and positive controls in both the bacterial and fungal assays were expressed as means \pm standard error for each test culture. The effects of the plant extracts on the test pathogens were compared by testing for significant difference in the means of zones of inhibition using one-way ANOVA at $1 \%$ and $5 \%$ level of confidence with $\mathrm{P}$ value $<0.05$ considered as significant. The significant means of the zones of inhibition were separated using multiple range test (Tukey HSD test).

\section{Results}

The ethnobotanical survey carried out in Transmara West, Narok County on the medicinal plants used by the local herbalists to treat diseases caused by Salmonella typhi, Shigella dysenteriae, Klebsiella pneumonia, Escherichia coli and Candida albicans revealed twenty two plants (Table 4.1). Roots, leaves and stem barks comprised the parts commonly used by the herbalists, with roots being the highest preferred and hence chosen for the assay. From the species of choice value model, eleven plant species, which were cited by the herbalists as the most commonly used by the Maasai Traditional Health practitioners were identified and recorded (Table 4.1). From these, eight plants were selected for antimicrobial screening after prioritization using participatory pair-wise ranking technique (Table 4.2).

The assay revealed remarkable differences both in the antimicrobial activities as well as the phytochemical composition of the plants under study (Table 4.2). The average diameters of zones of inhibition produced by the extracts against the test pathogens revealed various susceptibility levels ranging from resistant, intermediately resistant as well as susceptible (Table 4.3). Compared to other extracts whose MICs and MBCs were determined against $S$. typhi, C. abyssinica Jaub and Spach (Euphorbiaceae) had the highest activity with 
The efficacy of some medicinal plants used locally within Transmara west, Narok County, Kenya ..

MIC of $18.75 \mathrm{mg} / \mathrm{ml}$ and a similar MBC (Table 4.4). Pterolobium stellatum (Forssk.) Brenan (Fabaceae) and Carissa edulis (Forssk.) Vahl (Apocynaceae) showed similar MICs and MBCs of $37.50 \mathrm{mg} / \mathrm{ml}$ against S. typhi. Minimum Inhibitory Concentrations and MBCs of $37.50 \mathrm{mg} / \mathrm{ml}$ and $75.00 \mathrm{mg} / \mathrm{ml}$ respectively were exhibited by both Phyllanthus urinaria Linn (Phyllanthaceae) and Dovyalis abyssinica (A. Rich.) Warb (Flacourtiaceae) against the pathogen (Table 4.4).

The highest activity against $E$. coli was shown by $R$. prinoides L'He'r (Rhamnaceae) with MIC and MBC of $9.37 \mathrm{mg} / \mathrm{ml}$. Phyllanthus urinaria Linn (Phyllanthaceae) also showed a good activity with MIC and MBC of $18.75 \mathrm{mg} / \mathrm{ml}$ and $37.50 \mathrm{mg} / \mathrm{ml}$ respectively against E. coli with both Clerodendron myricoides (Hochst.) Vatke (Verbenaceae) and Dovyalis abyssinica (A. Rich.) Warb (Flacourtiaceae) showing similar MICs and MBCs of $37.50 \mathrm{mg} / \mathrm{ml}$. The extracts of both P. stellatum (Forssk.) Brenan (Fabaceae) and P. urinaria Linn (Phyllanthaceae) exhibited MICs and MBCs of $37.50 \mathrm{mg} / \mathrm{ml}$ and $75.00 \mathrm{mg} / \mathrm{ml}$ respectively against E. coli.

For $S$. dysenteriae, only two extracts showed promising antibacterial activity and were therefore screened for MIC and MBC. Clutia abyssinica Jaub and Spach (Euphorbiaceae) showed a relatively higher activity with MIC and MBC of $18.75 \mathrm{mg} / \mathrm{ml}$ and $37.50 \mathrm{mg} / \mathrm{ml}$ respectively. Phyllanthus urinaria Linn (Phyllanthaceae) had MIC of $37.50 \mathrm{mg} / \mathrm{ml}$ and MBC of $75.00 \mathrm{mg} / \mathrm{ml}$. The rest of the test extracts were not screened for MIC and MBC due to their low activity (zones of inhibition of $<9.0 \mathrm{~mm}$ ) against $S$. dysenteriae.

Against K. pneumoniae, Phyllanthus urinaria Linn (Phyllanthaceae) and Clutia abyssinica Jaub and Spach (Euphorbiaceae) showed similar and relatively higher activity with MICs and MBCs of $18.75 \mathrm{mg} / \mathrm{ml}$ and $37.50 \mathrm{mg} / \mathrm{ml}$ respectively while Carissa edulis (Forssk.) Vahl (Apocynaceae) and Clerodendron myricoides (Hochst.) Vatke (Verbenaceae) both had similar MICs and MBCs of $37.00 \mathrm{mg} / \mathrm{ml}$ (Table 4.4).

For C. albicans, Clutia abyssinica Jaub and Spach (Euphorbiaceae) showed the highest antifungal activity with MIC and MFC of $9.37 \mathrm{mg} / \mathrm{ml}$ which was close to the MIC and MFC of the positive control (4.69 $\mathrm{mg} / \mathrm{ml}$ ). Clerodendron myricoides (Hochst.) Vatke (Verbenaceae) also showed good activity with MIC of 9.37 $\mathrm{mg} / \mathrm{ml}$ and $\mathrm{MFC}$ of $18.75 \mathrm{mg} / \mathrm{ml}$ against the fungal pathogen.

\section{Tables}

Table 4.1: Some plant species used by herbalists in Transmara west to treat diseases caused by the test pathogens and other related ailments

\begin{tabular}{|c|c|c|c|c|}
\hline Botanical Name & Family & Vernacular Name & Part used & Diseases treated \\
\hline Acacia tortilis (Forssk.) Hayne & Fabaceae & Oltepesi & $\begin{array}{ll}\text { Roots, } & \text { Stem, } \\
\text { Leaves } & \end{array}$ & $\begin{array}{l}\text { Urinary tract infections, } \\
\text { Mouth infections }\end{array}$ \\
\hline Acacia xanthophloea Benth. & Fabaceae & Olerai & $\begin{array}{ll}\text { Roots, } & \text { Stem, } \\
\text { Leaves } & \end{array}$ & Pneumonia \\
\hline Achyranthes aspera $\mathrm{L}$. & Amaranthaceae & Olerobat & Roots, Leaves & $\begin{array}{ll}\begin{array}{l}\text { Candidiasis, } \\
\text { diseases }\end{array} & \text { Skin }\end{array}$ \\
\hline Albizia anthelmintica Brongn. & Fabaceae & Ormukutan & Roots, Stem & $\begin{array}{l}\text { Stomach ache, } \\
\text { Diarrhoea, Back ache }\end{array}$ \\
\hline Aloe volkensii Engl. & Asphodelaceae & Osukuroi & Leaves & $\begin{array}{l}\text { Stomach } \quad \text { ache, } \\
\text { Diarrhoea }\end{array}$ \\
\hline Blepharis linariifolia Pers. & Acanthaceae & Oltontolian & Roots, leaves & Pneumonia \\
\hline Carissa edulis (Forssk.) Vahl* & Apocynaceae & Olamuriaki & Roots & $\begin{array}{l}\text { Backaches, } \\
\text { Kidney problems, } \\
\text { Pneumonia } \\
\end{array}$ \\
\hline $\begin{array}{ll}\begin{array}{l}\text { Clerodendron } \\
\text { (Hochst.) Vatke }\end{array} & \text { myricoides } \\
\end{array}$ & Verbenaceae & Olmatukutuk & Roots & Candidiasis, gonorrhoea \\
\hline $\begin{array}{l}\text { Clerodendrum rotundifolium } \\
\text { Oliv.* }\end{array}$ & Verbenaceae & Osingarua & Leaves, Roots & Pneumonia \\
\hline $\begin{array}{l}\text { Clutia abyssinica } \text { Jaub and } \\
\text { Spach* }\end{array}$ & Euphorbiaceae & Olkiparnyeny & Roots & Candidiasis \\
\hline $\begin{array}{l}\text { Commiphora africana (A. Rich.) } \\
\text { Engl. }\end{array}$ & Burseraceae & Olchilishili & Roots, Stem & $\begin{array}{l}\text { Skin diseases, } \\
\text { Candidiasis }\end{array}$ \\
\hline Commiphora sp. & Asphodelaceae & Oltemuai & Roots, Stem & $\begin{array}{l}\text { Pneumonia, } \\
\text { Skin diseases }\end{array}$ \\
\hline $\begin{array}{lll}\text { Crotolaria } & \text { rotundifolia } & \text { J.F. } \\
\text { Gmel.* } & & \end{array}$ & Fabaceae & Oloniai & Roots & Candidiasis \\
\hline $\begin{array}{l}\text { Dovyalis abyssinica } \\
\text { (A. Rich.) Warb* }\end{array}$ & Flacourtiaceae & Olmorogi & Roots & Typhoid, Diarrhoea \\
\hline Echinops sphaerocephalus L.* & Asteraceae & Enkomereki & Roots, stem,leaves & Typhoid \\
\hline $\begin{array}{l}\text { Melhania } \\
\text { parvifolia Chiov. }\end{array}$ & Malvaceae & $\begin{array}{l}\text { Orporokwai- } \\
\text { lekop }\end{array}$ & Leaves & $\begin{array}{l}\text { Pneumonia and other } \\
\text { Lung related Problems }\end{array}$ \\
\hline Phyllanthus urinaria Linn* & Phyllanthaceae & Olmenangi & Roots, leaves & $\begin{array}{l}\text { Dysentery, } \\
\text { Diarrhoea, } \\
\text { Stomach ache }\end{array}$ \\
\hline $\begin{array}{l}\text { Pterolobium stellatum } \\
\text { (Forssk.) Brenan* }\end{array}$ & Fabaceae & Kinawa & $\begin{array}{l}\text { Roots, } \\
\text { Leaves }\end{array}$ & Pneumonia \\
\hline
\end{tabular}


The efficacy of some medicinal plants used locally within Transmara west, Narok County, Kenya ..

\begin{tabular}{|l|l|l|l|l|}
\hline Rhamnus prinoides L'He'r* & Rhamnaceae & Olkonyil & Roots, stem & $\begin{array}{l}\text { Typhoid } \\
\text { Stomach ache }\end{array}$ \\
\hline $\begin{array}{l}\text { Rhynchosia calycosa } \\
\text { Hemsl.* }\end{array}$ & Fabaceae & Osaei- Loldia & Roots & Pneumonia \\
\hline $\begin{array}{l}\text { Sericocomopsis hildebrandtii } \\
\text { Schinz. }\end{array}$ & Amaranthaceae & Olaisai & Roots, Leaves & Stomach ache, Malaria \\
\hline $\begin{array}{l}\text { Warburgia salutaris (Bertol.f.) } \\
\text { Chiov. }\end{array}$ & Canellaceae & Osokonoi & Roots, Stem & $\begin{array}{l}\text { Stomach ache, } \\
\text { Typhoid, Pneumonia }\end{array}$ \\
\hline
\end{tabular}

Key: * Plants most commonly used

Table 4.2: Means \pm standard error of the mean of zones of inhibition $(\mathrm{mm})$ against the test microorganisms

\begin{tabular}{|l|l|l|l|l|l|}
\hline TREATMENT & S. typhi & E. coli & S. dysenteriae & K. pneumaniae & C. albican \\
\hline Negative controls & $6.000 \pm 0.000 \mathrm{a}$ & $6.000 \pm 0.000 \mathrm{a}$ & $6.000 \pm 0.000 \mathrm{a}$ & $6.000 \pm 0.000 \mathrm{a}$ & $6.000 \pm 0.000 \mathrm{a}$ \\
\hline C. rotundifolium & $7.667 \pm 0.333 \mathrm{ab}$ & $6.667 \pm 0.333 \mathrm{ab}$ & $8.000 \pm 0.577 \mathrm{a}$ & $7.333 \pm 0.333 \mathrm{abc}$ & $7.333 \pm 0.333 \mathrm{ab}$ \\
\hline C. myricoides & $8.000 \pm 0.577 \mathrm{ab}$ & $10.667 \pm 1.201 \mathrm{~cd}$ & $6.667 \pm 0.333 \mathrm{a}$ & $10.333 \pm 0.333 \mathrm{bcd}$ & $14.000 \pm 0.577 \mathrm{c}$ \\
\hline C. edulis & $8.333 \pm 0.333 \mathrm{ab}$ & $7.667 \pm 0.333 \mathrm{abc}$ & $8.000 \pm 0.577 \mathrm{a}$ & $10.333 \pm 1.201 \mathrm{bcd}$ & $8.000 \pm 0.577 \mathrm{ab}$ \\
\hline D. abyssinica & $9.000 \pm 0.577 \mathrm{ab}$ & $9.667 \pm 0.881 \mathrm{abc}$ & $7.333 \pm 0.333 \mathrm{a}$ & $7.000 \pm 0.577 \mathrm{ab}$ & $9.000 \pm .577 \mathrm{ab}$ \\
\hline P. urinaria & $9.667 \pm 0.333 \mathrm{bc}$ & $13.667 \pm 0.881 \mathrm{de}$ & $12.000 \pm 1.154 \mathrm{c}$ & $12.667 \pm 0.881 \mathrm{~d}$ & $8.000 \pm 0.577 \mathrm{ab}$ \\
\hline P.stellutum & $10.000 \pm 0.573 \mathrm{bc}$ & $10.333 \pm 1.201 \mathrm{bcd}$ & $8.667 \pm 0.881 \mathrm{ab}$ & $7.333 \pm 0.333 \mathrm{abc}$ & $10.333 \pm 0.881 \mathrm{~b}$ \\
\hline$R$ R. prinoides & $12.333 \pm 0.881 \mathrm{~cd}$ & $14.667 \pm 0.881 \mathrm{e}$ & $7.333 \pm 0.333 \mathrm{a}$ & $8.667 \pm 0.881 \mathrm{abc}$ & $6.667 \pm 0.333 \mathrm{a}$ \\
\hline C. abyssinica & $14.000 \pm 0.577 \mathrm{~d}$ & $9.667 \pm 0.881 \mathrm{abc}$ & $11.667 \pm 0.881 \mathrm{bc}$ & $11.000 \pm 1.000 \mathrm{~cd}$ & $14.667 \pm 0.333 \mathrm{c}$ \\
\hline Positive controls & $28.333 \pm 1.201 \mathrm{e}$ & $28.667 \pm 0.333 \mathrm{f}$ & $28.000 \pm 0.577 \mathrm{~d}$ & $29.333 \pm 0.881 \mathrm{e}$ & $24.667 \pm 1.201 \mathrm{~d}$ \\
\hline P. value & $<\mathbf{0 . 0 0 1}$ & $<\mathbf{0 . 0 0 1}$ & $<\mathbf{0 . 0 0 1}$ & $<\mathbf{0 . 0 0 1}$ & $<\mathbf{0 . 0 0 1}$ \\
\hline
\end{tabular}

Key: The terms a, b, c, d, e, f show significant differences where applicable for the clusters

Table 4.3: Susceptibility levels shown by the test pathogens to the plant extracts and controls as exhibited by the means of zones of inhibition produced

\begin{tabular}{|l|l|l|l|l|l|}
\hline Botanical name of plant & S. typhi & E. coli & S. dysenteriae & K. pneumoniae & C. albicans \\
\hline$P$. stellatum (Forssk.) Brenan & S & S & I & I & S \\
\hline C. edulis (Forssk.) Vahl & I & I & I & S & I \\
\hline R. prinoides L'He'r & S & S & I & I & R \\
\hline P. urinaria Linn & S & S & S & S & I \\
\hline C. abyssinica Jaub and Spach & S & S & S & S & S \\
\hline C. rotundifolium Oliv & I & R & I & I & I \\
\hline C. myricoides (Hochst.) Vatke & I & S & R & S & S \\
\hline D. abyssinica (A. Rich.) Warb & S & S & I & I & S \\
\hline Positive controls & S & S & S & S & S \\
\hline Negative controls & - & - & - & - & - \\
\hline
\end{tabular}

Key: $\mathbf{R}$ represents Resistant

I represents intermediately resistant

$S$ represents Susceptible

- represents no inhibition

Table 4.4: MICs and MBCs/MFCs $(\mathrm{mg} / \mathrm{ml})$ produced by the medicinal plants and positive controls

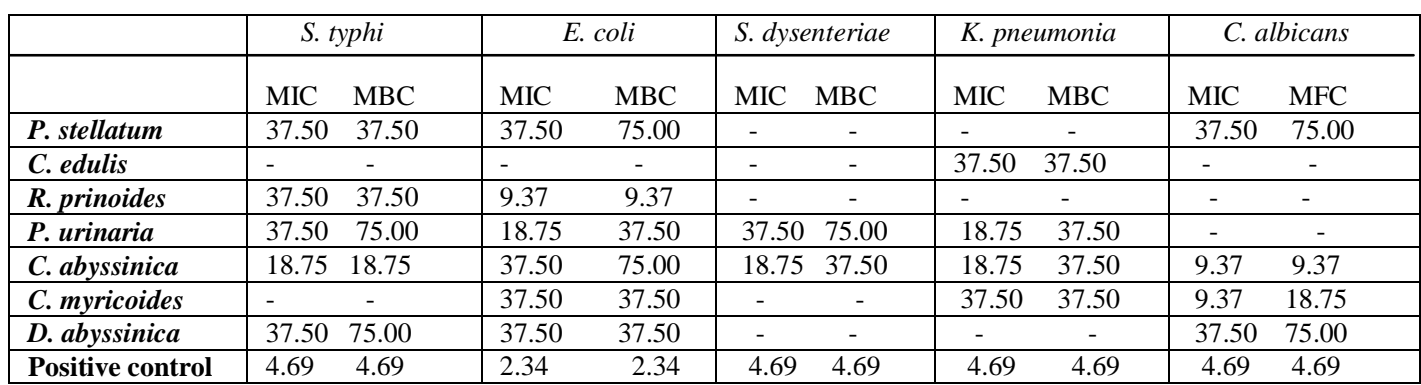

Positive control: Commercial antibiotics Ciprofloxacin (for bacterial isolates) and Fluconazole for (C. albicans)

- Represents MIC, MBC/MFC not determined due to low activity as revealed by mean zone of inhibition of $<9.00 \mathrm{~mm}$ 
The efficacy of some medicinal plants used locally within Transmara west, Narok County, Kenya ..

Table 4.5: Phytochemical screening of the extracts from the selected plant species

\begin{tabular}{|c|c|c|c|c|}
\hline Botanical name of plant & Tannins & Saponins & Flavonoids & Alkaloids \\
\hline $\begin{array}{llll}\begin{array}{l}\text { Pterolobium } \\
\text { (Fabaceae) }\end{array} & \text { stellatum } & \text { (Forssk.) } & \text { Brenan } \\
\end{array}$ & +++ & ++ & +++ & - \\
\hline Phyllanthus urinaria Linn (Phyllanthaceae) & +++ & ++ & + & + \\
\hline $\begin{array}{llll}\begin{array}{l}\text { Clutia abyssinica } \\
\text { (Euphorbiaceae) }\end{array} & \text { Jaub } & \text { and } & \text { Spach } \\
\end{array}$ & ++ & + & +++ & ++ \\
\hline Rhamnus prinoides L'He'r (Rhamnaceae) & +++ & + & + & ++++ \\
\hline $\begin{array}{lll}\begin{array}{l}\text { Clerodendrum } \\
\text { (Verbenaceae) }\end{array} & \text { rotundifolium } & \text { Oliv } \\
\end{array}$ & +++ & ++ & + & - \\
\hline $\begin{array}{l}\begin{array}{l}\text { Clerodendron myricoides (Hochst.) } \\
\text { (Verbenaceae) }\end{array} \\
\text { Vatke }\end{array}$ & + & - & ++ & +++ \\
\hline $\begin{array}{l}\begin{array}{l}\text { Dovyalis abyssinica } \\
\text { (Flacourtiaceae) }\end{array} \\
\text { (A. }\end{array}$ & ++ & ++ & - & + \\
\hline Carissa edulis (Forssk.) Vahl (Apocynaceae) & +++ & - & ++ & ++ \\
\hline
\end{tabular}

Key: +++ represents high quantity/ abundant

++ represents moderate quantity

+ represents low quantity/ trace

- represents absence

\section{Discussion}

The use of roots as the most preferred plant parts in the preparation of herbal medicines as revealed in the present survey could be because roots are believed to store higher concentrations of phytochemicals than other plant parts. Roots have a high partitioning for the photosynthates and exudates [41]. The high antimicrobial activity exhibited by Pterolobium stellatum (Forssk.) Brenan (Fabaceae) against S. typhi and E. coli may be attributed to the presence of high quantities of tannins and flavonoids in the plant (Table 4.5). These compounds have been shown to possess cytotoxic and antidiarrhoeal properties [41].

In a research conducted by Endale et al. (2014) [42], ethanol extracts from leaves of P. stellatum (Forssk.) Brenan (Fabaceae) showed significant in vitro anti-mycobacterial activity against Mycobacterium tuberculosis with MIC of $250 \mathrm{mg} / \mathrm{ml}$. Gizachew et al. (2014) [43] revealed that methanol extracts from the roots of $P$. stellatum (Forssk.) Brenan (Fabaceae) showed high activity against S. typhi, Salmonella paratyphi, $P$. aeruginosa, S. aureus and E. coli. Despite the significantly acclaimed antimicrobial value of Carissa edulis (Forssk.) Vahl (Apocynaceae) [44, 28, 45], the present study revealed that among the studied pathogens, the extracts from the plant were highly active only against $K$. pneumoniae. The relatively low antimicrobial activity of $C$. edulis (Forssk.) Vahl (Apocynaceae) in the present study may be due to phytochemicals antagonism and discrepancies in phytochemical composition as a result of seasonal differences [46]. It could also be as a result of intrinsic tolerance of the test microorganisms to the phytochemical combinations in the extracts of the plant [47]. Findings of Nedi et al. (2004) [48] show that Carissa edulis (Forssk.) Vahl (Apocynaceae) possesses medicinal properties effective in the management of tuberculosis and other ailments.

Presence of flavonoids in abundance and moderate amounts of tannins and alkaloids (Table 4.5) could possibly be contributory to the bacterial and fungal inhibitory nature of extracts from Clutia abyssinica Jaub and Spach (Euphorbiaceae) against $S$. typhi and C. albicans in the present study. This is due to the antibacterial and antifungal properties properties that have been attributed to tannins and alkaloids [41]. Methanol extracts of Clutia abyssinica Jaub and Spach (Euphorbiaceae) have also been found to possess antiplasmodial properties [49]. Resistance against Clerodendron myricoides (Hochst.) Vatke (Verbenaceae) by S. dysenteriae and the low inhibition against $S$. typhi by the plant may be due to phytochemical antagonism [46]. The significant inhibitory potency shown by extracts of Clerodendron myricoides (Hochst.) Vatke (Verbenaceae) against E. coli, K. pneumonia and $C$. albicans in this study is comparable to research findings of Aremu et al. (2010) [50] which revealed activity of extracts from $C$. myricoides (Hochst.) Vatke (Verbenaceae) against E. coli, K. pneumoniae and $C$. albicans with MICs of $3.13 \mathrm{mg} / \mathrm{ml}$ in all the microbes and MFC of $6.25 \mathrm{mg} / \mathrm{ml}$ against $C$. albicans. Resistance towards Clerodendrum rotundifolium Oliv (Verbenaceae) by E. coli despite the high quantities of tannins in the plant as revealed in the present assay can be as a result of tolerance towards tannins. It has been shown that many strains of bacteria possess tolerance mechanisms towards tannins [34].

The susceptibility of S. typhi, E. coli, S. dysenteriae and K. pneumonia to Phyllanthus urinaria Linn (Phyllanthaceae) could be attributed to synergy among tannins, saponins, flavonoids, alkaloids and other phytochemicals that may be present in the plant. This is from the assertion that for many herbal extracts, synergy among multiple constituents exists [51]. The large number of pharmacologically active compounds in the plant increases the likelihood of interactions taking place [52].

The variations in the antimicrobial potency of the plants extracts as revealed by the distinct inhibitory zones and the MICs could be as a result of differences in both composition and amount of phytochemicals among the plants studied as represented in the present research findings. This is in agreement to Akharaiyi and Boboye (2010) [20] who maintain that active medicinal plants, though effective on the microbial isolates tested 
The efficacy of some medicinal plants used locally within Transmara west, Narok County, Kenya ..

against may exhibit variations in inhibitory potency resulting from variations in the secondary metabolites concentrations in the plants. Variations in the sensitivity may also be attributed to the differences in growth rate of the tested organisms, nutritional requirements, temperature and inoculum size [53].

\section{Conclusion}

The results of the present study revealed that Pterolobium stellatum (Forssk.) Brenan (Fabaceae), Rhamnus prinoides L'He'r (Rhamnaceae), Phyllanthus urinaria Linn (Phyllanthaceae), Carissa edulis (Forssk.) Vahl (Apocynaceae), Clutia abyssinica Jaub and Spach (Euphorbiaceae), Clerodendrum rotundifolium Oliv (Verbenaceae), Clerodendron myricoides (Hochst.) Vatke (Verbenaceae) and Dovyalis abyssinica (A. Rich.) Warb (Flacourtiaceae) have a good antimicrobial activities against the studied Enterobacteria and fungal pathogens. We therefore recommend for their consideration as possible sources of antimicrobial agents in the development of additional drugs for management of Enterobacteria and Candida related infections. Further research should be carried out to investigate the safety of direct use of the extracts of the studied plants as medicine including their pharmacokinetics and pharmacological activities before their ethno medicinal use is validated.

\section{Acknowledgements}

We thank the Kenyatta National Hospital's Public Health Laboratories for providing us with the test cultures and the Kenyatta University's Chemistry, Pharmacy and Microbiology Departments for allowing us to use their laboratories in carrying out the various procedures and assays involved in the entire investigation.

\section{References}

[1]. Paterson, D. L. (2006). Resistance in gram-negative bacteria: Enterobacteriaceae. American Journal of Infectious Diseases Control, 34: 21-28.

[2]. Gupta, K., Hooton, T.M. and Naber, K. G. (2011). International clinical practice guidelines for the treatment of acute uncomplicated cystitis and pyelonephritis in women: a 2010 update by the Infectious Diseases Society of America and the European Society for Microbiology and Infectious Diseases. Clinical Infectious Diseases, 52: 103-120.

[3]. Hawser, S. P., Bouchillon, S. K., Lascols, C., Hackel, M., Hoban, D. J. and Badal, R. E. (2012). Susceptibility of European Escherichia coli clinical isolates from intra-abdominal infections, extended-spectrum betalactamase occurrence, resistance distribution, and molecular characterization of ertapenem-resistant isolates (SMART 2008-2009). Clinical Microbiology and Infectious diseases, 18: 253-259.

[4]. Thapar, N. and Sanderson, I.R. (2004). Diarrhoea in children: an interface between developing and developed countries. Lancet, 363: $641-653$

[5]. Sobel, J. D. (2009). Vulvovaginal candidiasis. Lancet, 369: 1961-1971.

[6]. Abdu, K. B., Khan, M. E. and Rumah M. M. (2008). Antimicrobial activity and phytochemical screening of extracts from the root bark of Carissa edulis, against human / animal pathogens. Continental Journal of Tropical Medicine, 2: $1-6$.

[7]. Yang, Y.S., Ku, C. H and Lin, J.C (2010). Impact of Extendedspectrum beta-lactamase producing Escherichia coli and Klebsiella pneumoniae on the outcome of community-onset bacteremic urinary tract infections. Journal of Microbiology Immunology and Infection, 43: 194-199.

[8]. Ben-Ami, R, Rodri'guez-Ban o, J. and Arslan, H. (2009). A multinational survey of risk factors for infection with extendedspectrum beta lactamase-producing enterobacteriaceae in nonhospitalized patients. Clinical Microbiology and Infectious Diseases, 49: 682-90.

[9]. Paterson, D. L. and Bonomo, R. A. (2005). Extended-spectrum betalactamases: a clinical update. Clinical Microbiology Reviews, 18: 657-686.

[10]. Nordmann, P., Naas, T. and Poirel, L. (2011). Global spread of carbapenemase producing Enterobacteriaceae. Emerg Infect Dis, 17: 1791-1798.

[11]. Cantón, R., Valverde, A., Novais, A., Baquero, F. and Coque, T. (2007). Evolution and current situation of ESBL. Enfermedades Infecciosas Microbiologia Clinica, 25: 2-10.

[12]. Namboodiri, S. S., Opintan, J. A., Lijek, R. S., Newman, M. J. and Okeke, N. I. (2011). Quinolone resistance in Escherichia coli from Accra, Ghana. BMC Microbiology, 11: 44.

[13]. Breurec, S., Guessennd, N., Timinouni, M., Le, T., Cao, V., Ngandjio, A., Randrianirina, F., Thiberge, J., Kinana, A., Dufougeray, A., Perrier-Gros-Claude, J., Boisier, P., Garin, B. and Brisse, S. (2013). Klebsiella pneumoniae resistant to third-generation cephalosporins in five African and two Vietnamese major towns: multiclonal population structure with two major international clonal groups, CG15 and CG258. Clinical Microbiology and Infectious Diseases, 19: 349-355.

[14]. Poirel, L., Potron, A. and Nordmann, P. (2012). OXA-48-like carbapenemases: the phantommenace. Journal of Antimicrobial Chemotherapy, 67: 1597-1606.

[15]. Woodford, N., Turton, J. F. and Livermore, D. M. (2011). Multiresistant Gram-negative bacteria: the role of high-risk clones in the dissemination of antibiotic resistance. FEMS Microbiology Reviews, 35: 736-755.

[16]. Papp-Wallace, K. M., Endimiani, A. Taracila, M. A., Bonomo, R. A. (2011). Carbapenems: Past, Present, and Future. Antimicrobial Agents and Chemotherapy, 55: 4943-4960.

[17]. Ojcius, D. (2007). In the News. Nature Reviews Microbiology, 5: 10-11.

[18]. Harrois, D., Breurec, S., Seck, A.,Delaunel, A.,, Le H., S., Pardos de la, M., Andara, G., Sontag, L., Perrier-Gros-Claude, J. D., Sire, J. M., Garin, B. and Weill, F. X. (2013). Prevalence and characterization of extended-spectrum b-lactamase-producing clinical Salmonella enterica isolates in Dakar, Senegal, from 1999 to 2009. Clinical Microbiology and Infection, doi: 10.1111/14690691.12339

[19]. Karuppayil, S. M., Rathod, V. S. and Raut, J. S. (2012). In vitro antifungal susceptibility reveals occurrence of azole resistance among clinical isolates of candida albicans. Asian Journal of Pharmaceutical and Clinical Research, 5: 170-173. 
The efficacy of some medicinal plants used locally within Transmara west, Narok County, Kenya ..

[20]. Akharaiyi, F. C. and Boboye, B. (2010). Antibacterial and Phytochemical Evaluation of Three Medicinal Plants. Journal of Natural Products, 3: 27-34

[21]. Ricardo, R. M. (2006). Bioactive Phytocompounds: New Approaches in the Phytosciences. Modern Phytomedicine, ISBN: 3-52731530-6. Accessed on $13^{\text {th }}$ December 2013.

[22]. Tajkarimi, M. M., Ibrahim, S. A. and Cliver, D. O. (2010). Antimicrobial herb and spice compounds in food. Food Control, 21:1199-1218.

[23]. Kiringe, J.W. (2006). A Survey of Traditional Health Remedies Used by the Maasai of Southern Kajiado District, Kenya. Ethnobotany Research and Applications, 4: 61-73.

[24]. Jeruto, P., Mutai, C., Ouma, G., Lukhoba, C., Nyamaka, R. L. and Manani, S. D. (2010). Ethnobotanical survey and propagation of some endangered medicinal plants from south Nandi district of Kenya. Journal of Animal and Plant Sciences, 8: 1016-1043.

[25]. Seema, D., Gupta, A. K. and Meenu, S. (2012). Ethano-Medicinal use of Plants Belonging to Families Fabaceae and Solanaceae, Hamirpur District (H.P.). International Journal of Scientific and Research Publications, 2: 3140- 3153

[26]. Kremen, V., Raymond, I., and Lances, K. (2008). An interdisciplinary tool for monitoring and conservation impacts in Madagascar. Conservation Biology, 12: 549-563.

[27]. Case, D. D. (1990). The Community's Toolbox: The idea, methods and tools for participatory assessment, monitoring and evaluation in community forestry. FAO/RWEDP, Rome.

[28]. Mariita, R. M., Okemo, P. O., Orodho, J. A., Kirimuhuzya, C. , Otieno, J. N. and Magadula, J. J. (2010). Efficacy of 13 medicinal plants used by indigenous communities around lake victoria, Kenya, against tuberculosis, diarrhea causing bacteria and Candida albicans. International Journal of Pharmacy and Technology, 2: 771-791.

[29]. Veeramuthu, D., Muniappan, A. and Savarimuthu, I. (2006). Antimicrobial activity of some ethnomedicinal plants used by Paliyar tribe from Tamil Nadu, India. BMC Complementary and Alternative Medicine, 6: 35-46.

[30]. Jorgensen, J. H. and Turnidge, J. D. (2007). Antibacterial susceptibility tests: dilution and disk diffusion methods. Manual of Clinical Microbiology, 9: 1152-1172.

[31]. Hleba, L., Kacaniova, M., Vukovic, N., Petrova, J., Felsociova, S., Pavelkova, A. and Rovna, K. (2013). Antibacterial activity of some wild medical plants extract to antibiotic resistant Escherichia coli. Journal of Microbiology, Biotechnology and Food Sciences, 2: 1215-1224.

[32]. Rani, P. and Khullar, N. (2004). Antimicrobial evaluation of some medicinal plants for their anti-enteric potential against multi-drug resistant Salmonella typhi. Phytotherapy research, 18: 670-673.

[33]. Giner, M. J., Vegara, S., Funes, L. Nuria, M., Saura, D., Micolb, V. and Valeroa, M. (2012). Antimicrobial activity of foodcompatible plant extracts and chitosan against naturally occurring micro-organisms in tomato juice. Journal of the Science of Food and Agriculture, 92: 1917-1923.

[34]. Wardah, M. D., Khoo, T. J., Ramliza, R., Tzar, M. N. and Christophe, W. (2013). Antibacterial Effects of Ellagitannins from Acalypha wilkesiana var. macafeana hort.:Surface Morphology Analysis with Environmental Scanning Electron Microcopy and Synergy with Antibiotics. Phytotherapy Research, 27: 1313-1320.

[35]. Edelmann, A., Pietzcke, T. and Wellinghausen, N. (2007). Comparison of direct disk diffusion and standard microtitre broth dilution susceptibility testing of blood culture isolates. Journal of Medical Microbiology, 56: 202-207.

[36]. Obasi, N. B. and Igbochi, A. C. (1992). Antibacterial activity of a chemical isolate from stem bark of Blighia unijugata. African Journal of Pharmacology and Pharmaceutical Science, 23: 4750 - 4761.

[37]. Soetan, K. O., Aiyelaagbe O. O., Oyekunle, M. A. and Fafunso, M. A. (2006). Evaluation of the antimicrobial activity of saponins extract of Sorghum bicolor L. Moench. African Journal of Biotechnology, 5: 2405-2407.

[38]. Edeoga, H. O., Okwu, D. E. and Mbaebie, B. O. (2005). Phytochemical constituents of some Nigerian medicinal plants. African Journal of Biotechnology. 4: 685-688.

[39]. Obadoni, B. O., and Ochuko, P. O. (2001). Phytochemical studies and comparative efficacy of the crude extracts of some homostatic plants in Edo and Delta states of Nigeria. Global Journal of Pure and Applied Science, 8: 203-208.

[40]. Okello, S. V., Nyunja, R. O., Netondo, G. W. and Onyango, J. C. (2010). Ethnobotanical study of medicinal plants used by Sabaots of Mt. Elgon. African Journal of Traditional, Complementary and Alternative Medicines, 7: 1- 10.

[41]. Atta, A. H. and Mouneir, S. M. (2005). Evaluation of some medicinal plant extracts for antidiarrhoeal activity. Phytotherapy Research, 19: 481- 485 .

[42]. Endale, B., Berhan, M., Mebrahtom, G., Adane, W. and Gobena, A. (2014). Evaluation of $I n$-vitro Anti-Mycobacterial Activity of Selected Medicinal Plants in Mekelle, Ethiopia. World Applied Sciences Journal, 31: 1217-1220.

[43]. Gizachew, A., Shemsu, U., Fentabi, G., Alemu, T., Haile, A. and Nigatu, K. (2014). Antimicrobial and Phytochemical Screening of Methanol Extracts of Three Medicinal Plants in Ethiopia. Advances in Biological Research, 8: 101-106.

[44]. Bussmann, R. W., Njoroge, G. N. and Grace, N. G. (2006). Diversity and utilization of antimalarial ethnotherapeutic remedies among the Kikuyus (Central Kenya). Journal of Ethnobiological Ethnomedicine, 2: 35- 41.

[45]. Jeruto, P. , Mutai, C., Lukhoba, C. and Ouma, G. (2011). Phytochemical constituents of some medicinal plants used by the Nandis of South Nandi district, Kenya. Journal of Animal and Plant Sciences, 9: 1201- 1210.

[46]. Ruttoh, E. K. (2009). Antimicrobial efficacy of selected plants use by traditional medical practioners in Kerio, Kenya. Nairobi, Kenya. M.Sc. Dissertation. Kenyatta University, 78-87.

[47]. Duraipandiyan, V. and Ignacimuthu, S. (2011). Antifungal activity of traditional medicinal plants from Tamil Nadu, India. Asian Pacific Journal of Tropical Biomedicine, 2: 204-215.

[48]. Nedi, T., Mekonnen, N. and Urgak, K. (2004). Diuretic effect of the crude extracts of Carissa edulis in rats. Journal of Ethnopharmacology, 95: 57-61.

[49]. Muthaura, C. N., Rukunga, G. M., Chhabra, S. C. Omar, S. A., Guantai. A. N., Gathirw, J. W.,Tolo, F. M., Mwitari, P. G., Keter, L. K.,Kirira, P. G. Kimani, C. W. Mungai, G. M. and Njagi, E. N. (2007). Antimalarial Activity of Some Plants Traditionally used in Meru district of Kenya. Phytotherapy Research, 21: 860-867.

[50]. Aremu, A. O., Ndhlala, A. R., Fawole, O. A., Light, M. E., Finnie, J. F. and Van Staden, J. (2010). In vitro pharmacological evaluation and phenolic content of ten South African medicinal plants used as anthelmintics. South African Journal of Botany, 76: 558-566.

[51]. Bensch, K., Tiralongo, J., Schmidt, K., Matthias, A., Bone, K. M., Lehmann, R., and Tiralongo. E. (2011). Investigations into the antiadhesive activity of herbal extracts against Campylobacter jejuni. Phytotherapy Research, 25: 1125-1132.

[52]. Enzo, A. P. (2006). Phytochemicals from Traditional Medicinal Plants used in the Treatment of Diarrhoea: Modes of Action and Effects on Intestinal Function. Phytotherapy research, 20: 717-724.

[53]. Gaill, W. and Jon, A. W., (1995). Antimicrobial susceptibility test; dilution and disc diffusion methods. Clinical Microbiology, 6 : 1327-1332. 